\title{
POTENSI DAN STRATEGI PENGEMBANGAN DESA SUMBERSALAK SEBAGAI DESA WISATA
}

\author{
Bagus Indra Tjayadhi \\ Program Studi Perhotelan Fakultas Ilmu Sosial dan Ilmu Politik \\ Universitas Muhammadiyah Jember \\ Email: bagusindra@unmuhjember.ac.id
}

\begin{abstract}
The purpose of this research is analyzing tourism potential and development strategic as a tourism village in Sumbersalak Village, Jember Regency. This research based on quantitative and qualitative method. Quantitive data based on from observations and interview with questionaires besides, the supporting data was from library resources.

Based on SWOT analysis result found the internal factors and external factor. The internal factors consist of (1) strength: beautiful natural resources and products from the village people, (2) weaknesess: Sumbersalak village need more development about human resources and infastucture, external factors (1) opportunity: the uniqueness of natural resources and people culture, (2) threat: competition of with other village in the development of rural tourism. Based on SWOT analysis obtained the development strategy for Sumbersalak village is using WO strategy. This strategy need to minimize most of the threat that they have and getting the big opportunity become good management of rural tourism.
\end{abstract}

Keywords : potential, development strategy, tourism village, SWOT analysis

\begin{abstract}
Abstrak
Tujuan dari penelitian ini adalah menganalisis potensi wisata dan strategi pengembangan sebagai desa wisata di Desa Sumbersalak, Kabupaten Jember. Penelitian ini didasarkan pada metode kuantitatif dan kualitatif. Data kuantitatif berdasarkan observasi dan wawancara dengan kuesioner disamping itu data pendukungnya berasal dari sumber perpustakaan. Berdasarkan hasil analisis SWOT didapatkan faktor internal dan faktor eksternal. Faktor internal terdiri dari (1) kekuatan: sumber daya alam yang indah dan produk dari masyarakat desa, (2) kelemahannya: Desa Sumbersalak membutuhkan lebih banyak pengembangan sumber daya manusia dan infrastruktur, faktor eksternal (1) peluang: keunikan sumber daya alam dan budaya masyarakat, (2) ancaman: persaingan dengan desa lain dalam pengembangan wisata pedesaan. Berdasarkan analisis SWOT diperoleh strategi pengembangan desa Sumbersalak menggunakan strategi WO. Strategi ini perlu meminimalkan sebagian besar ancaman yang mereka miliki dan mendapatkan peluang besar menjadi manajemen wisata pedesaan yang baik.
\end{abstract}

Kata kunci : potensi, strategi pengembangan, desa wisata, SWOT. 


\section{Pendahuluan}

\section{Latar Belakang}

Pariwisata saat ini memiliki peran yang cukup signifikan terhadap pertumbuhan perekonomian Indonesia. Sesuai dengan data dari Kementrian Pariwisata melalui laman resminya www.kemenpar.go.id menyatakan bahwa pada tahun 2014 komoditas pariwisata telah menjadi komoditas penghasil devisa negara nomor empat setelah komoditas karet dengan nilai ekspor sebesar 11.166,3 (Juta USD). Dalam perkembangannya komoditas pariwisata senantiasa melibatkan sektor lain yang merupakan komponen pendukungnya sesuai Undang-Undang No 10 Tahun 2009 tentang Kepariwisataan, komponen yang masuk dalam industri pariwisata adalah: (1) Usaha jasa pariwisata, yang mencakup jasa biro perjalanan wisata; jasa agen perjalanan wisata; jasa pramuwisata; jasa konvensi, perjalanan insentif dan pameran; jasa impresariat; jasa konsultan pariwisata; jasa informasi pariwisata. (2) Pengusahaan obyek dan daya tarik wisata, yang mencakup pengusahaan obyek dan daya tarik wisata alam; pengusahaan obyek dan daya tarik wisata budaya; pengusahaan obyek dan daya tarik wisata minat khusus. (3) Usaha sarana pariwisata, yang mencakup penyediaan akomodasi; penyediaan makanan dan minuman; penyediaan angkutan wisata; penyediaan sarana wisata tirta; kawasan pariwisata.

Kabupaten Jember dalam laman resminya www.jemberkab.go.id menyatakan bahwa secara geografis dengan luas wilayah sekitar $3.293,34 \mathrm{~km}^{2}$ memiliki sekitar 10 obyek wisata alam yang tersebar diberbagai desa di 31 kecamatan. Desa Sumbersalak merupakan salah satu desa yang terletak di kaki Gunung Raung dengan ketinggian berkisar \pm 1000 meter diatas permukaan laut dengan luas desa sekitar 6558,213 Ha. Dengan panorama alam yang masih asri Desa Sumbersalak memiliki beberapa obyek dan daya tarik wisata yang salah satunya adalah air terjun. Air terjun tersebut berjumlah tiga buah dan memiliki kekhasan tersendiri, yaitu selain karena lokasinya saling berdekatan, bentuknya bertingkat yang menurut masyarakat setempat menyerupai air Terjun Niagara di benua Amerika, sehingga masyarakat sekitar memberikan nama air terjun tersebut sebagai Niagara Mini, meskipun menurut tokoh masyarakat setempat sejarahnya air terjun yang terdapat di Desa Sumbersalak tersebut telah memiliki nama yaitu air terjun Damar Wulan I, Damar Wulan II dan Anjasmoro. Selain 
air terjun, Desa Sumbersalak yang berada di Kecamatan Ledokombo ini juga memiliki produk lokal berupa cemilan khas dan kerajinan tangan.

\section{Tujuan}

Berdasarkan pada rumusan masalah diatas, maka tujuan penelitian yang ingin dicapai adalah untuk:

1) Menganalisis dan mendeskripsikan potensi wisata yang dimiliki oleh Desa Sumbersalak.

2) Merumuskan strategi pengembangan Desa Sumbersalak sebagai Desa Wisata Di Kabupaten Jember.

\section{Metode Penelitian}

\section{Lokasi Dan Waktu Penelitian}

Penelitian ini akan dilakukan di Desa Sumbersalak, Kecamatan Ledokombo, Kabupaten Jember. Lokasi berjarak sekitar 30 Kilometer dari Kota Jember. Penelitian dilaksanakan pada Bulan Februari sampai dengan April 2017.

\section{Metode Penelitian}

Metode yang digunakan dalam penelitian ini adalah metode kualitatif dan kuantitatif yang selanjutnya dianalisis secara kuantitatif. Data-data yang diperoleh dengan cara wawancara, studi literatur dan melalui kuesioner selanjutnya dianalisis menggunakan analisis SWOT.

\section{Hasil Dan Pembahasan}

\section{Gambaran Umum}

Nama Desa Sumbersalak terdiri dari kata 'Sumber' yang berarti sumber mata air dan 'Salak' yang berarti buah salak yang menurut sejarah konon di Desa Sumbersalak terdapat sumber mata air yang berada tepat dibawah Pohon Salak. Terdapat versi lain dari dari sejarah Desa Sumbersalak yaitu kata 'Salak' yang diambil dari Bahasa Madura yaitu 'Sellak' yang berarti berdesakan yang dalam hal ini adalah sumber mata air yang berdesakan. Pada kenyataannya di Desa Sumbersalak banyak terdapat sumber mata air yang muncul di sekitar persawahan. Sumber mata air terbesar terletak di Dusun Karang Anyar dan Dusun Juroju. Desa Sumbersalak merupakan salah satu desa dari rangkaian desa yang mengelilingi kaki Gunung Raung. Hal ini merupakan salah satu faktor wilayah Desa Sumbersalak memiliki tanah yang subur sehingga sebagian besar penduduk Desa Sumbersalak bermata pencaharian sebagai petani dan ditambah sumber mata air yang melimpah sehingga membuat penduduk Desa Sumbersalak tidak pernah kekurangan air. 


\section{Identifikasi Potensi Lingkungan}

\section{Internal Dan Eksternal}

Berdasarkan hasil penelitian bahwa

Desa Sumbersalak memiliki faktor internal dan faktor eksternal. Identifikasi dari faktor internal dan faktor eksternal yang dimiliki oleh Desa Sumbersalak digunakan untuk menentukan strategi yang tepat untuk mengembangkan potensi wisata yang dimiliki oleh Desa Sumbersalak. Berikut adalah tabel faktor internal dan eksternal yang dimiliki oleh Desa Sumbersalak.

Tabel 1. Faktor-Faktor Internal Desa Sumbersalak

Kekuatan (strengths)

1. Sumber daya alam yang melimpah berupa lahan pertanian, perkebunan dan sumber mata air yang mengaliri sungai di sepanjang Desa Sumbersalak.

2. Kondisi lingkungan yang sejuk karena berada di lereng Gunung Raung.

3. Atraksi wisata berupa air terjun, di Desa Sumbersalak terdapat 3 buah air terjun dengan posisi yang saling berdekatan dan masing-masing memiliki kekhasan tersendiri, yaitu Air Terjun Damar Wulan I, Damar Wulan II dan Air Terjun Anjasmoro.

4. Mulai tumbuhnya kegiatan ekonomi masyarakat setempat berkaitan dengan aktivitas pariwisata yang mulai berkembang di tempat-tempat yang berdekatan dengan atraksi wisata.

5. Produk masyarakat yang dihasilkan oleh kelompok-kelompok masyarakat Desa Sumbersalak yang tidak hanya berupa produk makanan dan minuman tradisional tetapi juga produk penunjang pertanian.

6. Sikap masyarakat yang ramah dan terbuka kepada pendatang di desanya sebagai konsekuensi adanya atraksi wisata yang mulai dikembangkan oleh masyarakat setempat.

7. Tingkat keamanan khususnya untuk pengunjung dari luar Desa Sumbersalak mendapatkan perhatian sehingga membuat rasa aman.

Kelemahan (weaknesess)

1. Jarak dari pusat kota Jember sekitar 30 kilometer membuat waktu tempuh menuju ke Desa Sumbersalak tidak bisa ditempuh dalam waktu singkat.

2. Aksesbilitas menuju ke atraksi wisata di Desa Sumbersalak yang masih terbatas membuat tidak semua jenis kendaraan dapat masuk hingga mendekati lokasi atraksi wisata.

3. Sarana penunjang wisata yang belum layak bagi wisatawan yang mengunjungi atraksi wisata di Desa Sumbersalak.

4. Pengelolaan daya tarik wisata yang belum maksimal dikarenakan terdapat beberapa tempat yang masih sangat baru pengelolaannya.

5. Belum terdapatnya layanan informasi pada saat berada dilokasi baik berupa brosur, poster maupun petugas yang memberikan informasi bagi pengunjung yang ingin mengetahui informasi lebih banyak mengenai atraksi-atraksi wisata yang ada di Desa Sumbersalak.

6. Penataan lingkungan yang belum maksimal dikarenakan sebagian besar mata 
pencaharian penduduk desa adalah bertani, bukan berkaitan langsung dengan kegiatan kepariwisataan.

7. Kualitas kebersihan lingkungan yang belum mencerminkan kesiapan dari Desa Sumbersalak dalam menerima kunjungan wisatawan.

8. Tingkat promosi tentang Desa Sumbersalak kepada wisatawan masih belum maksimal dan masih berkesan dari swadaya masyarakat dengan keterbatasan kemampuan yang dimiliki.

Sumber: Olahan Peneliti 2017

Tabel 2. Faktor-Faktor Eksternal Desa Sumbersalak

\section{Faktor Peluang}

1. Potensi lain yang dimiliki oleh Desa Sumbersalak selain atraksi wisata adalah berbagai macam produksi makanan, minuman dan aneka produk masyarakat lainnya dalam menunjang kegiatan kepariwisataan di Desa Sumbersalak masih belum dikembangkan secara maksimal.

2. Atraksi wisata yang dimiliki oleh Desa Sumbersalak menjadi obyek wisata baru yang masih baru dan masih belum dikenal oleh masyarakat secara luas, dikarenakan kegiatan operasional pengelolaan obyek wisata masih dibawah tiga tahun.

3. Paket wisata di Desa Sumbersalak untuk wisatawan dalam kelompok/grup.

4. Peningkatan kesadaran masyarakat tentang pariwisata semakin lama akan semakin baik seiring dengan semakin banyaknya organisasi baik dari pemerintah, swasta maupun dari akademisi yang telah berkunjung dan memberikan bantuan berupa program pelatihan dan pengembangan berkaitan dengan potensi-potensi yang dimiliki oleh Desa Sumbersalak.

5. Kunjungan wisatawan mancanegara ke Jawa Timur tahun 2015 menurut BPS Jawa Timur sebesar 200,851 kunjungan.

6. Telah dibentuknya Kelompok Masyarakat Sadar Wisata di Desa Sumbersalak sebagai pihak pengelola obyek wisata yang ada didesa Sumbersalak.

7. Dukungan pemerintah berupa program pelatihan dan pengembangangan potensi desa melalui dinas-dinas terkait seperti Dinas Pariwisata dan Dinas Perisndustrian dan Perdagangan.

\section{Faktor Ancaman}

1. Adanya obyek wisata sejenis yang berada di Desa Sumberlesung, yaitu desa tetangga yang berada dalam satu kecamatan.

2. Perubahan lingkungan dikarenakan pada saat ini terdapat potensi lain yaitu pariwisata yang bermanfaat bagi masyarakat yang pada awalnya lebih banyak memanfaatkan lingkungannya di sektor pertanian.

3. Perilaku masyarakat yang berubah dikarenakan harus mampu beradaptasi dengan semakin banyaknya pendatang yang masuk ke Desa Sumbersalak sebagai dampak dari aktivitas pariwisata di desa tersebut.

4. Wilayah yang terdapat kegiatan kepariwisataan masih terbatas pada di sekitar obyek wisata, sehingga pada wilayah itu banyak terdapat aktivitas perekonomian baru tetapi tidak setiap warga memperoleh kesempatan yang sama.

5. Semakin banyaknya pendatang yang akan memasuki wilayah Desa Sumbersalak akan memiliki pengaruh terhadap budaya lokal masyarakat setempat.

Sumber: Olahan Peneliti 2017 
Hasil Analisis Faktor Internal dan

\section{Eksternal Desa Sumbersalak}

Hasil analisis dalam penelitian ini meliputi faktor-faktor internal dan eksternal di Desa Sumbersalak Kabupaten Jember yang digunakan untuk penyusunan strategi pengembangan desa wisata. Tahapan analisis dengan melakukan observasi ke lapangan dan wawancara terhadap para responden. Berdasarkan hasil kuesioner tersebut diketahui bahawa hasil dari bobot, rating dan skor seperti pada tabel berikut ini:

Tabel 3. Matriks IFAS Desa Sumbersalak

\begin{tabular}{|c|c|c|c|}
\hline Faktor-Faktor Internal & Bobot & Rating & Skor \\
\hline Kekuatan : & & & \\
\hline $\begin{array}{l}\text { 1. Sumber daya alam yang melimpah berupa lahan } \\
\text { pertanian, perkebunan dan sumber mata air yang } \\
\text { mengaliri sungai di sepanjang Desa Sumbersalak. }\end{array}$ & 0,079 & 2,640 & 0,209 \\
\hline $\begin{array}{l}\text { 2. Kondisi lingkungan yang sejuk karena berada di } \\
\text { lereng Gunung Raung. }\end{array}$ & 0,075 & 2,600 & 0,195 \\
\hline $\begin{array}{l}\text { 3. Atraksi wisata berupa air terjun, di Desa } \\
\text { Sumbersalak terdapat } 3 \text { buah air terjun dengan } \\
\text { posisi yang saling berdekatan dan masing-masing } \\
\text { memiliki kekhasan tersendiri, yaitu Air Terjun } \\
\text { Damar Wulan I, Damar Wulan II dan Air Terjun } \\
\text { Anjasmoro. }\end{array}$ & $\mathbf{0 , 0 8 0}$ & 2,680 & 0,214 \\
\hline $\begin{array}{l}\text { 4. Mulai tumbuhnya kegiatan ekonomi masyarakat } \\
\text { setempat berkaitan dengan aktivitas pariwisata yang } \\
\text { mulai berkembang di tempat-tempat yang } \\
\text { berdekatan dengan atraksi wisata. }\end{array}$ & 0,065 & 2,520 & 0,164 \\
\hline $\begin{array}{l}\text { 5. Produk masyarakat yang dihasilkan oleh kelompok- } \\
\text { kelompok masyarakat Desa Sumbersalak yang tidak } \\
\text { hanya berupa produk makanan dan minuman } \\
\text { tradisional tetapi juga produk penunjang pertanian. }\end{array}$ & 0,060 & 2,480 & 0,149 \\
\hline $\begin{array}{l}\text { 6. Sikap masyarakat yang ramah dan terbuka kepada } \\
\text { pendatang di desanya sebagai konsekuensi adanya }\end{array}$ & 0,065 & 3,160 & 0,205 \\
\hline
\end{tabular}




\begin{tabular}{|c|c|c|c|}
\hline $\begin{array}{l}\text { atraksi wisata yang mulai dikembangkan oleh } \\
\text { masyarakat setempat. } \\
\text { 7. Tingkat keamanan khususnya untuk pengunjung } \\
\text { dari luar Desa Sumbersalak mendapatkan perhatian } \\
\text { sehingga membuat rasa aman. }\end{array}$ & 0,050 & 2,800 & 0,140 \\
\hline Sub Total Faktor Kekuatan & 0,47 & - & 1,28 \\
\hline $\begin{array}{l}\text { Kelemahan: } \\
\text { 1. Jarak dari pusat kota Jember sekitar } 30 \text { kilometer } \\
\text { membuat waktu tempuh menuju ke Desa } \\
\text { Sumbersalak tidak bisa ditempuh dalam waktu } \\
\text { singkat. }\end{array}$ & 0,075 & $-2,440$ & $-0,183$ \\
\hline $\begin{array}{l}\text { 2. Aksesbilitas menuju ke atraksi wisata di Desa } \\
\text { Sumbersalak yang masih terbatas membuat tidak } \\
\text { semua jenis kendaraan dapat masuk hingga } \\
\text { mendekati lokasi atraksi wisata. }\end{array}$ & $\mathbf{0 , 0 7 8}$ & $-2,840$ & $-0,222$ \\
\hline $\begin{array}{l}\text { 3. Sarana penunjang wisata yang belum layak bagi } \\
\text { wisatawan yang mengunjungi atraksi wisata di Desa } \\
\text { Sumbersalak. }\end{array}$ & 0,075 & $-2,600$ & $-0,195$ \\
\hline $\begin{array}{l}\text { 4. Pengelolaan daya tarik wisata yang belum } \\
\text { maksimal dikarenakan terdapat beberapa tempat } \\
\text { yang masih sangat baru pengelolaannya. }\end{array}$ & 0,059 & $-2,400$ & $-0,142$ \\
\hline $\begin{array}{l}\text { 5. Belum terdapatnya layanan informasi pada saat } \\
\text { berada dilokasi baik berupa brosur, poster maupun } \\
\text { petugas yang memberikan informasi bagi } \\
\text { pengunjung yang ingin mengetahui informasi lebih } \\
\text { banyak mengenai atraksi-atraksi wisata yang ada di } \\
\text { Desa Sumbersalak. }\end{array}$ & 0,050 & $-2,720$ & $-0,136$ \\
\hline $\begin{array}{l}\text { 6. Penataan lingkungan yang belum maksimal } \\
\text { dikarenakan sebagian besar mata pencaharian } \\
\text { penduduk desa adalah bertani, bukan berkaitan } \\
\text { langsung dengan kegiatan kepariwisataan. }\end{array}$ & 0,055 & $-2,800$ & $-0,154$ \\
\hline
\end{tabular}




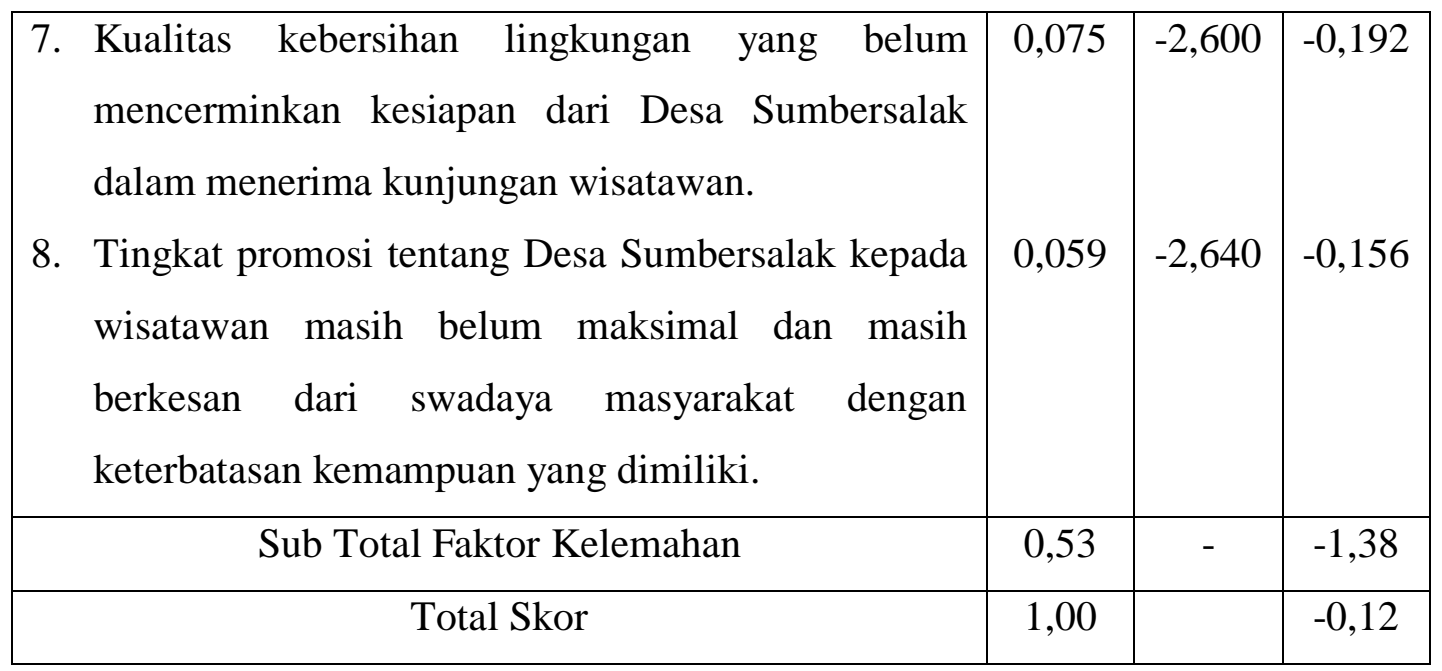

Sumber: Olahan Peneliti (2017)

Berdasarkan tabel 3 bahwa faktorfaktor kekuatan Desa Sumbersalak dari skor tertinggi pertama dengan nilai 0,214 adalah atraksi wisata. Atraksi wisata yang berada di Desa Sumbersalak adalah berupa air terjun, di desa ini terdapat 3 buah air terjun dengan posisi yang saling berdekatan sehingga wisatawan dapat menikmati ketiga air terjun tersebut tanpa harus berjalan cukup jauh dari satu air terjun ke air terjun yang lain. Air terjun tersebut adalah Air Terjun Damar Wulan I, Damar Wulan II dan Air Terjun Anjasmoro. Walaupun letak ketiga air terjun ini saling berdekatan tetapi ketiganya tetap memiliki keunikan masing-masing baik secara bentuk dan luasnya. Wisatawan dapat menikmati suasana desa yang alami sepanjang perjalanan dari satu air terjun ke air terjun yang lain.
Sedangkan kelemahan utama pada tabel diatas dengan nilai sebesar $-0,222$ adalah mengenai aksesbilitas menuju ke atraksi wisata di Desa Sumbersalak yang masih terbatas, sehingga tidak semua jenis kendaraan dapat masuk hingga mendekati lokasi atraksi wisata. Selain jenis jalan disekitar obyek wisata masih alami (tanah), luas jalan juga sangat terbatas. Terdapat jalur alternatif untuk mencapai lokasi atraksi wisata tetapi tetap memerlukan perbaikan sehingga memudahkan wisatawan untuk mencapai lokasi atraksi wisata. Jalan hot mix masih sangat terbatas pada jalan desa belum menjangkau obyek wisata, sehingga wisatawan banyak mengeluhkan jenis jalan yang masih berupa tanah menjadi becek dan berlumpur apabila terkena hujan deras. 
Analisis lingkungan eksternal Factor Analysis Summary) pada tabel 4 menggunakan tabel EFAS (External dibawah ini:

Tabel 3. Matriks IFAS Desa Sumbersalak

\begin{tabular}{|c|c|c|c|}
\hline Faktor-Faktor Strategi Eksternal & Bobot & Rating & Skor \\
\hline $\begin{array}{l}\text { Peluang: } \\
\text { 1. Potensi lain yang dimiliki oleh Desa Sumbersalak } \\
\text { selain atraksi wisata adalah berbagai macam } \\
\text { produksi makanan, minuman dan aneka produk } \\
\text { masyarakat lainnya dalam menunjang kegiatan } \\
\text { kepariwisataan di Desa Sumbersalak masih belum } \\
\text { dikembangkan secara maksimal. }\end{array}$ & 0,080 & 2,640 & 0,211 \\
\hline $\begin{array}{l}\text { 2. Atraksi wisata yang dimiliki oleh Desa } \\
\text { Sumbersalak menjadi obyek wisata baru yang } \\
\text { masih baru dan masih belum dikenal oleh } \\
\text { masyarakat secara luas, dikarenakan kegiatan } \\
\text { operasional pengelolaan obyek wisata masih } \\
\text { dibawah tiga tahun. }\end{array}$ & 0,075 & 2,760 & 0,207 \\
\hline $\begin{array}{l}\text { 3. Paket wisata di Desa Sumbersalak untuk wisatawan } \\
\text { dalam kelompok/grup. }\end{array}$ & 0,085 & 2,600 & 0,221 \\
\hline $\begin{array}{l}\text { 4. Peningkatan kesadaran masyarakat tentang } \\
\text { pariwisata semakin lama akan semakin baik seiring } \\
\text { dengan semakin banyaknya organisasi baik dari } \\
\text { pemerintah, swasta maupun dari akademisi yang } \\
\text { telah berkunjung dan memberikan bantuan berupa } \\
\text { program pelatihan dan pengembangan berkaitan } \\
\text { dengan potensi-potensi yang dimiliki oleh Desa } \\
\text { Sumbersalak. }\end{array}$ & 0,075 & 2,560 & 0,192 \\
\hline $\begin{array}{l}\text { 5. Kunjungan wisatawan mancanegara ke Jawa Timur } \\
\text { tahun } 2015 \text { menurut BPS Jawa Timur sebesar } \\
\text { 200,851 kunjungan. }\end{array}$ & $\mathbf{0 , 1 0 0}$ & 2,640 & 0,264 \\
\hline $\begin{array}{l}\text { 6. Telah dibentuknya Kelompok Masyarakat Sadar } \\
\text { Wisata di Desa Sumbersalak sebagai pihak } \\
\text { pengelola obyek wisata yang ada didesa } \\
\text { Sumbersalak. } \\
\text { 7. Dukungan pemerintah berupa program pelatihan } \\
\text { dan pengembangangan potensi desa melalui dinas- } \\
\text { dinas terkait seperti Dinas Pariwisata dan Dinas } \\
\text { Perisndustrian dan Perdagangan. }\end{array}$ & 0,085 & 2,920 & 0,248 \\
\hline Total Faktor Peluang & 0,58 & - & 1,60 \\
\hline $\begin{array}{l}\text { Ancaman: } \\
\text { 1. Adanya obyek wisata sejenis yang berada di Desa } \\
\text { Sumberlesung, yaitu desa tetangga yang berada } \\
\text { dalam satu kecamatan. } \\
\text { 2. Perubahan lingkungan dikarenakan pada saat ini }\end{array}$ & $\mathbf{0 , 1 0 0}$ & $-2,680$ & $-0,268$ \\
\hline
\end{tabular}




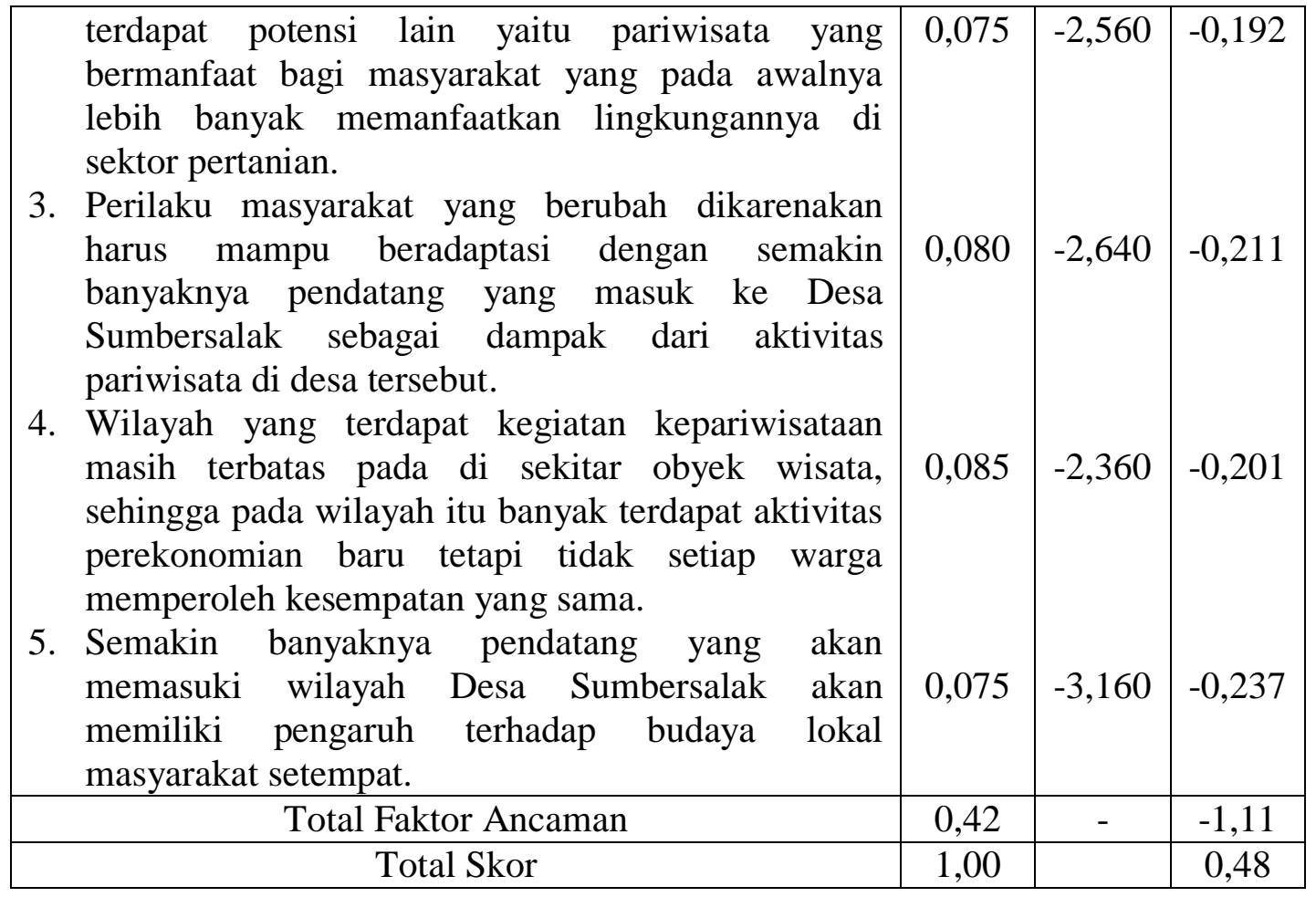

Sumber: Olahan Peneliti (2017)

Berdasarkan tabel 4 diatas dapat kita ketahui bahwa peluang tertinggi dengan nilai sebesar 0,264 adalah kunjungan wisatawan mancanegara ke Jawa Timur tahun 2015 menurut BPS Jawa Timur sebesar 200,851 kunjungan. Desa Sumbersalak yang memiliki potensi wisata alam nantinya akan berpeluang untuk mendapatkan kunjungan dari wisatawan mancanegara, hal ini didukung oleh telah tersedianya Bandara Notohadinegoro Jember dengan rute penerbangan dari Surabaya menuju Jember dan sebaliknya sehingga dapat mempersingkan waktu tempuh wisatawan yang ingin berkunjung ke Jember. Selain itu saat ini Kabupaten Jember telah memiliki sejumlah even wisata dengan skala nasional maupun internasional seperti halnya even JFC (Jember Fashin Carnaval) yang diselenggarakan pada setiap tahun. Di Kecamatan Ledokombo sebagai kecamatan dimana letak Desa Sumbersalak berada, telah berkembang kampung wisata yang bernama "Tanoker Ledokombo" yang awalanya adalah sebuah komunitas bermain anak-anak. Saat ini komunitas tersebut sudah sangat berkembang, hal ini ditandai dengan pelaksanaan berbagai even yang pengunjungnya tidak hanya dari masyarakat Kabupaten Jember tetapi juga masyarakat dari luar Kabupaten Jember hingga dari mancanegara. 
Faktor ancaman tertinggi dengan nilai sebesar -0,268 adalah adanya obyek wisata sejenis yang berada di Desa Sumberlesung, yaitu desa tetangga yang berada dalam satu kecamatan. Obyek wisata tersebut adalah berupa air terjun. Meskipun saat ini pengelolaan obyek wisata di Desa Sumberlesung hampir tidak jauh berbeda dengan Desa Sumbersalak akan tetapi apabila Desa Sumbersalak tidak segera membenahi model pengelolaan obyek wisata yang ada saat ini maka bukan tidak mungkin wisatawan akan lebih tertarik berkunjung ke Desa Sumberlesung walaupun berada dalam satu kecamatan yang sama.

\section{Analisis Matriks Internal Dan}

\section{Eksternal}

Berdasarkan hasil analisis pada matriks IFAS terhadap faktor-faktor lingkungan internal terdapat di Desa Sumbersalak seperti yang telah dijelaskan tersebut diatas diperoleh hasil bahwa nilai skor untuk faktor kekuatan adalah 1,28 dan nilai skor untuk faktor kelemahan adalah -1,40 sehingga skor untuk faktor kekuatan Desa Sumbersalak masih lebih besar dibandingkan dengan faktor kelemahannya. Sedangkan untuk hasil analisis berdasarkan matriks EFAS bahwa untuk faktor peluang memperoleh skor sebesar 1,60. Untuk faktor ancaman memperoleh skor sebesar -1,11. Dengan demikian maka skor untuk faktor peluang di Desa Sumbersalak masih lebih besar dibandingkan dengan faktor ancamannya.

Dari hasil pengolahan faktor-faktor internal dan eksternal yang dimiliki oleh Desa Sumbersalak kemudian digambarkan dalam diagram kartesius SWOT, dimana faktor kekuatan dan peluang diberi nilai positif (+) dan faktor kelemahan dan ancaman diberi nilai negatif (-). Diagram Kartesius SWOT dapat dilihat pada gambar dibawah ini. 


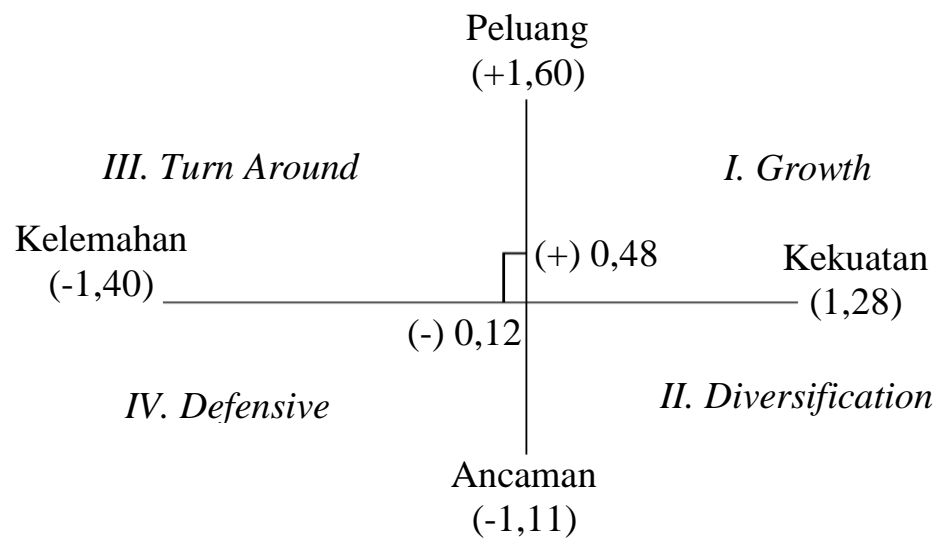

Gambar 1. Diagram Kartesius SWOT Desa Sumbersalak

Sumber: Olahan Peneliti (2017)

Berdasarkan diagram kartesius SWOT pada gambar 1, dapat dilihat bahwa potensi wisata Desa Sumbersalak berada pada kuadran III yang berarti bahwa strategi yang digunakan adalah strategi Weaknesess-Opportunities (WO) yang disebut juga sebagai strategi turn around. Jika melihat dari hasil analisis diatas menunjukkan bahwa saat ini Desa Sumbersalak menghadapi peluang yang besar tetapi dilain pihak masih menghadapi beberapa kelemahan internal.

Perhatian pengelolaan kegiatan pariwisata adalah dengan meminimalkan permasalahan yang ada dalam internal desa sehingga dapat merebut peluang yang lebih besar lagi. Faktor kelemahan yang dapat diperbaiki adalah yang terbesar mengenai aksesbilitas dalam menjangkau obyek-obyek wisata yang ada di Desa Sumbersalak. Perbaikan kualitas aksesbilitas menuju ke obyek wisata dapat menjadi fokus rencana perbaikan kelemahan dalam pengelolaan pariwisata di Desa Sumbersalak. Perbaikan aksesbilitas juga dapat dilakukan pada jalan yang menjadi penghubung ke tempat-tempat lain yang terdapat potensi wisata di Desa Sumbersalak misalnya mengunjungi tempat-tempat produksi khas desa yang dikelola oleh kelompok masyarakat yang ada di Desa Sumbersalak. Sehingga terdapat variasi obyek wisata yang nantinya dapat dinikmati oleh wisatawan, sehingga tidak 
hanya obyek wisata air terjun saja atau obyek wisata alam lainnya.

Perbaikan dan penambahan sarana penunjang aktivitas pariwisata seperti lahan parkir yang luas, tempat ibadah, rumah-rumah makan yang layak dengan harga menu yang terjangkau dan memiliki ciri khas Desa Sumbersalak. Penyediaan sarana akomodasi berupa penginapan sederhana tetapi layak bersih bagi wisatawan yang berasal dari luar kota, sehingga wisatawan tersebut tidak perlu kembali ke kota hanya untuk mencari penginapan dan besoknya kembali lagi ke desa. Penggunaan rumah-rumah penduduk desa yang dianggap layak sebagai akomodasi ditambah syarat lain misalnya rumah harus memiliki ciri khas yang mencerminkan Desa Sumbersalak. Penambahan pusat informasi di obyek wisata yang berkaitan dengan lokasi obyek wisata di Desa Sumbersalak, informasi sejarah obyek wisata, pramuwisata lokal, perlu mendapat perhatian khusus untuk ditingkatkan lagi kuantitasnya, sehingga wisatawa yang datang dapat dengan mudag mendapatkan informasi mengenai obye wisata secara khusus maupun informasi mengenai Desa Sumbersalak. Informasi yang berkaitan promosi juga perlu ditingkatkan kuantitasnya di area yang merupakan pintu masuk ke Kabupaten Jember tidak hanya sekedar promosi melalui media internet.

Penggunaan tiket masuk terpadu ke obyek wisata dapat diterapkan dalam pengelolaan obyek wisata, hal ini dikarenakan dengan adanya tiket masuk maka pengelola obyek dapat mengetahui jumlah pemasukan keuangan melalui pembelian tiket dan dapat mengetahui jumlah wisatawan yang berkunjung ke obyek wisata. Bagi wisatawan dengan pembelian satu tiket masuk dapat memudahkan wisatawan untuk mengunjungi obyek wisata apa saja yang terdapat di Desa Sumbersalak dengan hanya satu kali pembayaran.

Strategi berikutnya yang dapat dilakukan di Desa Sumbersalak adalah memanfaatkan setiap peluang yang ada untuk menjadikan Desa Sumbersalak menjadi sebuah desa wisata. Dengan adanya pengembangan dari paket wisata yang telah dikelola oleh POKDARWIS Desa Sumbersalak selama ini, diharapkan wisatawan dapat mengunjungi potensipotensi wisata lain yang dimiliki Desa Sumbersalak selain dari obyek wisata yang telah diketahui. Misalnya produksi kelompok-kelompok masyarakat lokal yang telah ada disana dengan harapan wisatawan membeli produk tersebut untuk 
dijadikan sebagai oleh-oleh sebagai ciri khas Desa Sumbersalak.

Oleh-oleh juga dapat berfungsi sebagai media promosi bagi Desa Sumbersalak bagi calon wisatawan yang belum mengetahui adanya potensi di desa tersebut dan tidak hanya mengandalkan media promosi yang selama ini telah berjalan. Selain itu dukungan pihak pemerintah dan swasta melalui kerjasama pelatihan dan program-program lain yang bertujuan untuk meningkatkan kualitas sumber daya manusia khususnya yang berkaitan dengan pengelolaan obyek wisata dan peningkatan kualitas sarana dan prasarana diobyek wisata untuk senantiasa ditingkatkan baik oleh pemerintah desa dan lembaga-lembaga desa yang berkaitan dengan pengelolaan desa sebagai wujud untuk meningkatkan kualitas Desa Sumbersalak sehingga dapat menjadi Desa Wisata.

\section{Strategi Alternatif Pengembangan Desa} Sumbersalak

Hasil perhitungan faktor-faktor internal dan ekternal yang terdapat di Desa Sumbersalak berdasarkan hasil perhitungan dari tabel 3 dan tabel 4 dapat dirumuskan formulasi arah strategi dengan menggunakan matriks SWOT yang dikembangkan oleh Weihrich (dalam Solihin, 2012:169). Matriks tersebut merupakan salah satu cara untuk mendapatkan strategi alternatif dengan cara menggabungkan masing-masing faktor yang meliputi strategi SO (Strenghts-Opportunities), strategi WO (Weaknesses-Opportunities), strategi ST (Strenght-Threats) dan strategi WT (Weaknesses-Threats). Dari hasil pengolahan data untuk strategi dari matriks SWOT untuk Desa Sumbersalak adalah: 
Tabel 5. Matriks SWOT Desa Sumbersalak

\begin{tabular}{|c|c|c|}
\hline EFAS & $\begin{array}{l}\text { KEKUATAN (S) } \\
\text { 1. Sumber daya alam yang } \\
\text { melimpah. } \\
\text { 2. Kondisi lingkungan yang } \\
\text { sejuk. } \\
\text { 3. Atraksi wisata berupa air } \\
\text { terjun } \\
\text { 4. Mulai tumbuhnya } \\
\text { kegiatan ekonomi } \\
\text { masyarakat. } \\
\text { 5. Produk masyarakat yang } \\
\text { dihasilkan oleh } \\
\text { kelompok masyarakat } \\
\text { Desa Sumbersalak. } \\
\text { 6. Sikap masyarakat yang } \\
\text { ramah dan terbuka } \\
\text { kepada pendatang. } \\
\text { 7. Tingkat keamanan. }\end{array}$ & $\begin{array}{l}\text { KELEMAHAN (W) } \\
\text { 1. Jarak dari pusat kota } \\
\text { Jember. } \\
\text { 2. Aksesbilitas menuju ke } \\
\text { atraksi wisata di Desa } \\
\text { Sumbersalak. } \\
\text { 3. Sarana penunjang wisata. } \\
\text { 4. Pengelolaan daya tarik } \\
\text { wisata. } \\
\text { 5. Belum terdapatnya } \\
\text { layanan informasi. } \\
\text { 6. Penataan lingkungan } \\
\text { yang belum maksimal. } \\
\text { 7. Kualitas kebersihan } \\
\text { lingkungan. } \\
\text { 8. Tingkat promosi tentang } \\
\text { Desa Sumbersalak. }\end{array}$ \\
\hline PELUANG (O) & STRATEGI (S-O) & $\mathrm{v}-\mathrm{C}$ \\
\hline 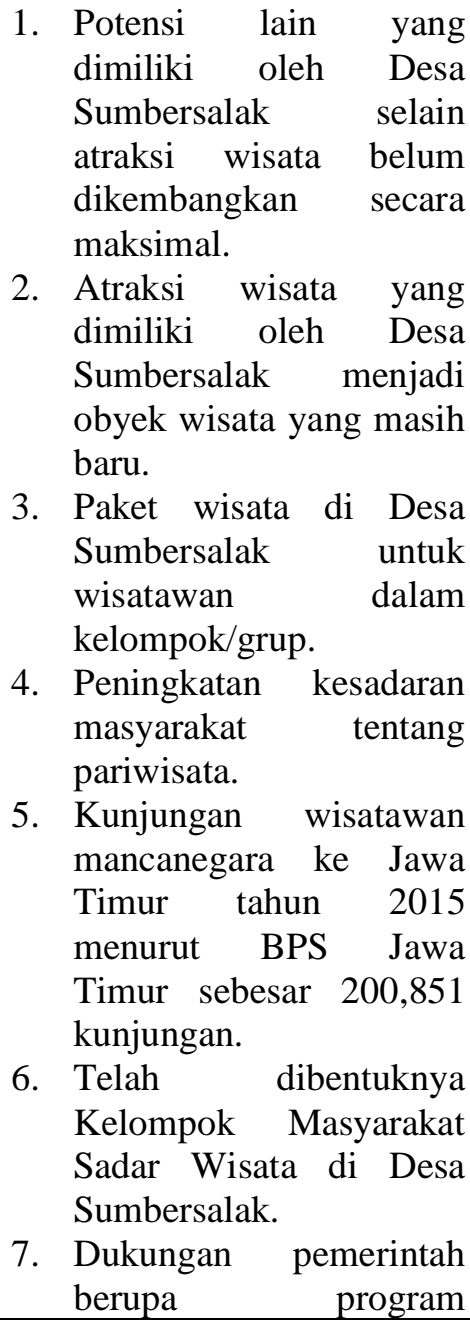 & $\begin{array}{l}\text { 1. Melakukan penataan } \\
\text { yang lebih baik lagi } \\
\text { dalam pengelolaan obyek } \\
\text { wisata. } \\
\text { 2. Pengembangan produk } \\
\text { lokal masyarakat } \\
\text { menjadi produk yang } \\
\text { lebih memiliki daya } \\
\text { saing. } \\
\text { 3. Pengembangangan paket } \\
\text { wisata dalam dalam satu } \\
\text { desa dengan harga lebih } \\
\text { kompetitif dan } \\
\text { penambahan fasilitas } \\
\text { lain. } \\
\text { 4. Menjalin kerjasama } \\
\text { dengan pihak lain baik } \\
\text { pemerintah, swasta } \\
\text { maupun akademisi untuk } \\
\text { dapat membangun desa } \\
\text { secara bersama-sama. }\end{array}$ & $\begin{array}{l}\text { 1. Memperbaiki kualitas } \\
\text { dan meningkatkan } \\
\text { jumlah sarana dan } \\
\text { prasarana di obyek } \\
\text { wisata. } \\
\text { 2. } \begin{array}{l}\text { Menjalin kerja sama } \\
\text { dengan pihak travel }\end{array} \\
\text { agent dalam menawarkan } \\
\text { paket wisata, tidak hanya } \\
\text { berpromosi melalui } \\
\text { media online dan offline. } \\
\text { 3. } \begin{array}{l}\text { Mengadakan program } \\
\text { pelatihan ar dan }\end{array} \\
\text { pengembangan bagi } \\
\text { masyarakat melalui kerja } \\
\text { sama dengan pihak lain. }\end{array}$ \\
\hline
\end{tabular}




\begin{tabular}{|c|c|c|}
\hline $\begin{array}{ll}\text { pelatihan } & \text { dan } \\
\text { pengembangangan } & \\
\text { potensi desa. } & \end{array}$ & & \\
\hline $\begin{array}{l}\text { ANCAMAN (T) } \\
\text { 1. Adanya obyek wisata } \\
\text { sejenis yang berada di } \\
\text { dalam satu kecamatan. } \\
\text { 2. Perubahan lingkungan. } \\
\text { 3. Perilaku masyarakat } \\
\text { yang berubah. } \\
\text { 4. Wilayah yang terdapat } \\
\text { kegiatan wisata masih } \\
\text { terbatas. } \\
\text { 5. Semakin banyaknya } \\
\text { pendatang yang akan } \\
\text { memasuki wilayah Desa } \\
\text { Sumbersalak. }\end{array}$ & $\begin{array}{l}\text { STRATEGI (S-T) } \\
\text { 1. Menambah fasilitas } \\
\text { outbond di sekitar obyek } \\
\text { wisata sebagai salah satu } \\
\text { nilai lebih di Desa } \\
\text { Sumbersalak. } \\
\text { 2. Memperluas wilayah } \\
\text { yang dapat di akses oleh } \\
\text { wisatawan sehingga } \\
\text { wisatawan dapat semakin } \\
\text { lama menghabiskan } \\
\text { waktu di obyek wisata. }\end{array}$ & $\begin{array}{l}\text { STRATEGI (W-T) } \\
\text { 1. Mempertahankan } \\
\text { perilaku dan budaya asli } \\
\text { masyarakat untuk } \\
\text { menambah kearifan lokal } \\
\text { di obyek wisata. } \\
\text { 2. Mempertahankan } \\
\text { lingkungan menjadi tetap } \\
\text { alami dengan konsep } \\
\text { ecotourism } \\
\text { 3. Membatasi jumlah } \\
\text { wisatawan yang } \\
\text { berkumpul pada obyek } \\
\text { wisata tertentu dengan } \\
\text { memberikan informasi } \\
\text { tempat-tempat lain yang } \\
\text { di Desa Sumbersalak } \\
\text { yang menarik untuk } \\
\text { dikunjungi. }\end{array}$ \\
\hline
\end{tabular}

Sumber: Hasil Analisis Data, 2017

Dari hasil analisis strategi berdasarkan tabel diatas dapat dirumuskan beberapa program yang mendukung strategi pengembangan Desa Sumbersalak menjadi desa wisata, adalah sebagai berikut:

\section{Strategi SO (Strengths Opportunities)}

Strategi ini adalah dengan memanfaatkan seluruh faktor kekuatan yang dimiliki Desa Sumbersalak untuk mendapatkan peluang yang dimilikinya. Strategi SO dilakukan melalui beberapa upaya, antara lain adalah:

a) Melakukan penataan yang lebih baik lagi dalam pengelolaan obyek wisata. b) Pengembangan produk lokal masyarakat menjadi produk yang lebih memiliki daya saing.

c) Pengembangan paket wisata dalam dalam satu desa dengan harga lebih kompetitif dan penambahan fasilitas lain.

d) Menjalin kerjasama dengan pihak lain baik pemerintah, swasta maupun akademisi untuk dapat membangun desa secara bersamasama.

\section{Strategi ST (Strengths Threats)}

Strategi ST adalah menggunakan semua faktor kekuatan yang dimiliki untuk mengatasi ancaman, strategi yang dapat diterapkan oleh Desa Sumbersalak dalam 
menghadapi ancaman adalah sebagai berikut:

a) Menambah fasilitas outbond di sekitar obyek wisata sebagai salah satu nilai lebih di Desa Sumbersalak.

b) Memperluas wilayah yang dapat di akses oleh wisatawan sehingga wisatawan dapat semakin lama menghabiskan waktu di obyek wisata.

\section{Strategi WO}

(Weaknesses

\section{Opportunities)}

Strategi ini digunakan dengan cara meminimalkan kelemahan yang ada di Desa Sumbersalak untuk memanfaatkan peluang yang ada sehingga dapat mengembangkan potensi wisata. Strategi WO tersebut adalah sebagai berikut:
a) Memperbaik
kualitas
dan meningkatkan jumlah sarana dan prasarana di obyek wisata.

b) Menjalin kerja sama dengan pihak travel agent dalam menawarkan paket wisata, tidak hanya berpromosi melalui media online dan offline.

c) Mengadakan program pelatihan dan pengembangan bagi masyarakat melalui kerja sama dengan pihak lain.

\section{Strategi WT (Weaknesses Threats)}

Strategi WT berdasarkan kepada bentuk kegiatan yang memiliki sifat defensif atau strategi yang meminimalkan kelemahan dan menghindari ancaman dengan cara pengelolaan sumber daya alam dan sumber daya manusia melalui upaya antara lain adalah:

a) Mempertahankan perilaku dan budaya asli masyarakat untuk menambah kearifan lokal di obyek wisata.

b) Mempertahankan lingkungan menjadi tetap alami dengan konsep ecotourism

c) Membatasi jumlah wisatawan yang berkumpul pada obyek wisata tertentu dengan memberikan informasi tempat-tempat lain yang di Desa Sumbersalak yang menarik untuk dikunjungi.

\section{Kesimpulan Dan Saran}

\section{Kesimpulan}

Dari hasil analisis faktor-faktor strategis lingkungan tersebut diatas, Desa Sumbersalak berada pada kuadran III yang berarti bahwa Desa Sumbersalak memiliki faktor-faktor kelemahan yang terdapat dalam pengelolaan potensi wisata di wilayahnya, tetapi juga memiliki peluang untuk dapat mengembangkan potensi wisata yang ada untuk menjadi Desa Wisata. Sehingga untuk menjadi sebuah Desa Wisata maka Desa Sumbersalak dapat menerapkan strategi WO (weaknesess-opportunities) dengan 
cara meminimalisir segala kelemahan yang dimiliki untuk mendapatkan peluang yang lebih besar lagi.

Faktor kelemahan yang dapat diperbaiki mulai yang terbesar, yaitu mengenai aksesbilitas dalam menjangkau obyek-obyek wisata yang ada di Desa Sumbersalak. Perbaikan kualitas aksesbilitas menuju ke obyek wisata dapat menjadi fokus rencana perbaikan kelemahan dalam pengelolaan pariwisata di Desa Sumbersalak. Perbaikan aksesbilitas juga dapat dilakukan pada jalan yang menjadi penghubung ke tempat-tempat lain yang terdapat potensi wisata di Desa Sumbersalak misalnya mengunjungi tempat-tempat produksi khas desa yang dikelola oleh kelompok masyarakat yang ada di Desa Sumbersalak. Sehingga terdapat variasi obyek wisata yang nantinya dapat dinikmati oleh wisatawan, sehingga tidak hanya obyek wisata air terjun saja atau obyek wisata alam lainnya.

Perbaikan dan penambahan sarana penunjang aktivitas pariwisata seperti lahan parkir yang luas, tempat ibadah, rumah-rumah makan yang layak dengan harga menu yang terjangkau dan memiliki ciri khas Desa Sumbersalak. Penyediaan sarana akomodasi berupa penginapan sederhana tetapi layak dan terjamin kebersihannya terutama bagi wisatawan yang berasal dari luar kota, sehingga wisatawan tersebut tidak perlu pergi ke kota hanya untuk mencari penginapan terlebih dahulu dan besoknya kembali lagi ke desa dikarenakan jarak tempuh yang cukup jauh dari kota menuju Desa Sumbersalak. Penggunaan rumah-rumah penduduk desa yang dianggap layak sebagai akomodasi ditambah syarat lain misalnya rumah harus memiliki ciri khas yang mencerminkan Desa Sumbersalak.

Penambahan pusat informasi di obyek wisata yang berkaitan dengan lokasi obyek wisata di Desa Sumbersalak, informasi sejarah obyek wisata, pramuwisata lokal, perlu mendapat perhatian khusus untuk ditingkatkan lagi kuantitasnya, sehingga wisatawa yang datang dapat dengan mudag mendapatkan informasi mengenai obye wisata secara khusus maupun informasi mengenai Desa Sumbersalak. Informasi yang berkaitan promosi juga perlu ditingkatkan kuantitasnya di area yang merupakan pintu masuk ke Kabupaten Jember tidak hanya sekedar promosi melalui media internet.

Penggunaan tiket masuk terpadu ke obyek wisata dapat diterapkan dalam pengelolaan obyek wisata, hal ini dikarenakan dengan adanya tiket masuk 
maka pengelola obyek dapat mengetahui jumlah pemasukan keuangan melalui pembelian tiket dan dapat mengetahui jumlah wisatawan yang berkunjung ke obyek wisata. Bagi wisatawan dengan pembelian satu tiket masuk dapat memudahkan wisatawan untuk mengunjungi obyek wisata apa saja yang terdapat di Desa Sumbersalak dengan hanya satu kali pembayaran.

Sedangkan untuk mendapatkan peluang sebesar-besarnya maka strategi dalam pengelolaan pariwisata Desa Sumbersalak adalah dengan mengembangkan paket wisata yang telah dikelola oleh POKDARWIS Desa Sumbersalak selama ini, diharapkan wisatawan dapat mengunjungi potensipotensi wisata lain yang dimiliki Desa Sumbersalak selain dari obyek wisata yang telah diketahui. Misalnya produksi kelompok-kelompok masyarakat lokal yang telah ada disana dengan harapan wisatawan membeli produk tersebut untuk dijadikan sebagai oleh-oleh sebagai ciri khas Desa Sumbersalak.

Oleh-oleh khas desa juga dapat berfungsi sebagai media promosi bagi Desa Sumbersalak bagi calon wisatawan yang belum mengetahui adanya potensi di desa tersebut dan tidak hanya mengandalkan media promosi yang selama ini telah berjalan. Selain itu dukungan pihak pemerintah dan swasta melalui kerjasama pelatihan dan programprogram lain yang bertujuan untuk meningkatkan kualitas sumber daya manusia khususnya yang berkaitan dengan pengelolaan obyek wisata dan peningkatan kualitas sarana dan prasarana diobyek wisata untuk senantiasa ditingkatkan baik oleh pemerintah desa dan lembaga-lembaga desa yang berkaitan dengan pengelolaan desa sebagai wujud untuk meningkatkan kualitas Desa Sumbersalak sehingga dapat menjadi Desa Wisata.

\section{Saran}

Berdasarkan hasil dari pembahasan dan kesimpulan, maka saran yang dapat diberikan peneliti adalah:

\section{Saran bagi pengelola}

Pihak yang saat ini mengelola obyekobyek wisata di Desa Sumbersalak harus meningkatkan upaya pengelolaan baik dari segi pengelolaan sumber daya manusia, keuangan, keamanan dan segala aspek yang berkaitan dengan aktivitas pariwisata yang terdapat di Desa Sumbersalak. Dengan demikian maka wisatawan akan merasa bahwa antara harapan dan kenyataan yang mereka dapatkan di Desa Sumbersalak menjadi sesuai dengan promosi yang dilakukan 
selama ini. Apabila wisatawan merasa kecewa dikarenakan antara harapan yang terbangun dari promosi yang dilakukan oleh pengelola obyek wisata di Desa Sumbersalak tidak sesuai dengan kenyataan yang didapatkan oleh wisatawan dilapangan maka akan membuat pencitraan Desa Sumbersalak sebagai desa wisata akan menjadi negatif.

Jalinan kerjasama antara pihak desa dengan pihak-piha eksternal misalnya bekerja sama dengan pihak perguruan tinggi untuk bersama-sama memajukan Desa Sumbersalak adalah merupakan salah satu trategi yang dapat diterapkan dalam jangka waktu dekat.

\section{Saran bagi masyarakat}

Pihak masyarakat desa hendaknya bisa memahami akan potensi wisata yang dimiliki oleh desanya yang memungkinkan dapat membawa kemajuan bagi Desa Sumbersalak. Melalui pemerintah desa hendaknya masyarakat desa telah mulai diberikan pemahaman bersama mengenai lingkunga, sikap dan berbagai hal lain yang berkaitan dengan pariwisata. Sehingga akan tumbuh kesadaran masyarakat untuk bersama-sama berada dalam satu visi untuk membangun pariwisata di wilayahnya.

\section{Saran bagi penelitian lanjutan}

Penelitian ini terbatas pada strategi pengelolaan, maka dapat disarankan untuk penelitian berikutnya untuk dapat lebih mengkaji dari segi pemasaran dan pemgembangan sumber daya manusia dalam pengelolaan pariwisata di Desa Sumbersalak.

\section{Ucapan Terima Kasih}

Peneliti menyampaikan terima kasih kepada berbagai pihak, khususnya kepada seluruh civitas Akademi Pariwisata Muhammadiyah Jember yang telah membantu penulisan penelitian ini. Peneliti juga menyampaikan terima kasih kepada segenap redaksi Jurnal Mediakom yang telah mempublikasikan artikel hasil penelitian ini. 


\section{Daftar Pustaka}

Bachri, S. Bachtiar.2010.Meyakinkan Validitas Data Melalui Triangulasi Pada Penelitian Kualitatif. Jurnal Teknologi Pendidikan (Volume 10, No 1).Surabaya.UNESA

Demartoto, Argyo. 2008. Strategi Pengembangan Obyek Wisata Pedesaan Oleh Pelaku Wisata Di Kabupaten Boyolali. Laporan Penelitian. Surakarta: Universitas Sebelas Maret Surakarta.

Dewi, Urmila Heny Made, Chafid Fandeli, Baiquni

M.2013.Pengembangan Desa

Wisata Berbasis Partisipasi Masyarakat Lokal Di Desa Wisata Jatiluwih Tabanan, Bali. Jurnal Kawistara (Volume 3, No 2). Yogyakarta: UGM.

Dharmawan, I Made, I Made Sarjana, I Dewa Ayu Sri Yudhari.2014.Strategi Pengembangan Desa Wisata Di Desa Belimbing Kecamatan Pupuan Kabupaten

Tabanan.Denpasar:Udayana

Herawati, Tuty. 2011. Model Pemberdayaan Masyarakat Desa Dan Penanggulangan Kemiskinan Melalui Pengembangan Desa Wisata Di Depok. Jurnal Ekonomi
Dan Bisnis (Volume 10, No 2). Jakarta: Poltek Negeri Jakarta Khodyat, H., Ramaini. 1992.Kamus Pariwisata Dan

Perhotelan.Jakarta:Gramedia

Kusmayadi, Endar

Sugiarto.2000.Metodologi

Penelitian Dalam Bidang

Kepariwisataan. Jakarta: PT.

Gramedia Pustaka Utama

Madiun, Nyoman I. 2010. Nusa Dua Model Pengembangan Kawasan Wisata Modern. Denpasar: Udayana University press.

Marzuki. 1997. Metodologi Riset. Yogyakarta: BPFE-UII

Nuryanti, Wiendu. 1993. Concept, Perspective and Challenges, makalah bagian dari Laporan Konferensi Internasional mengenai Pariwisata Budaya. Yogyakarta: Gadjah MadaUniversity Press. Hal. $2-3$

Pendit, I Nyoman, S. 1994. Ilmu Pariwisata Sebuah Pengantar Perdana. Jakarta: Pradnya Paramita Rangkuti, Freddy. 2002. Analisis SWOT Teknik Membedah Kasus Bisnis. Jakarta: PT Gramedia Pustaka Utama.

Riduwan. 2006. Belajar Mudah Penelitian. Bandung: Alfabeta 
Sabana, Choliq, Dkk. 2016. Kajian Strategi Tempat Pelelangan Ikan (TPI) Kota Pekalongan. Jurnal Litbang Kota Pekalongan. Pekalongan: Dewan Riset Daerah Pekalongan.

Sinclair, M.T., dan Stabler, M., 1997. The Economics of Tourism. London: Routledge.

Solihin, Ismail. 2000. Manajemen Strategik. Erlangga. Jakarta: Erlangga
Sunarti, Pratiwi, S., dan Mawardi, Kholid, M. 2017. Analisis SWOT Pada UMKM Keripik Tempe Amel Malang Dalam Rangka Meningkatkan Daya Saing Perusahaan. Jurnal Administrasi Bisnis (Vol. 43, No. 1 Februari 2017). Malang: Universitas Brawijaya.

Suwantoro, G. 1997. Dasar-dasar Pariwisata. Yogyakarta: Andi.

Spillane, James J. 1987. Ekonomi Pariwisata Sejarah dan Prospeknya. Yogyakarta: Kanisius. 